\title{
IS COLLATERAL CIVILIAN DAMAGE PART OF THE WEST'S STRATEGY TO WIN WARS?
}

DOI: $10.20542 / 2307-1494-2020-2-220-223$

Cronin B. Bugsplat: the Politics of Collateral Damage in Western Armed Conflicts. - New York: Oxford University Press, 2018. 256 p.

In his recent book, Bruce Cronin, Professor of Political Science and Department Chair at the Colin Powell School for Civic and Global Leadership at the City College of New York, explains that civilian casualty rates are highest during wars of attrition, civil wars, and counterinsurgency campaigns. However, in Chapters 3 to 6, he studies cases that do not fit into any of these three categories of war, but nevertheless resulted in high levels of civilian fatalities: the 1991 Persian Gulf War, the 1999 NATO air war against Yugoslavia, the 2006 Israeli-Hezbollah war, and the U.S. war against al-Qaeda since 2001. Indeed, in all these wars, the Western states fought against qualitatively weaker opponents and mostly on the territory of the opponents, which means there was no threat to the former's territorial integrity or survival. According to Cronin, armed conflicts that are characterized by asymmetry of threat should result in low numbers of civilian casualties. However, this was not the case in the aforementioned conflicts, and Cronin's mission is to explain why.

Collateral damage: whom to blame? In chapter 1, the author lists two different narratives that political and military leaders have used to explain such a high level of collateral damage. The first narrative blames the opponents for intentionally keeping their civilians close to military forces and thus blurring the line between civilian objects and military assets. The alternative version asserts that collateral damage cannot be prevented in any military action. For instance, during and following the 1991 war in the Gulf, the Pentagon blamed Iraqi authorities for purposefully not evacuating civilians and keeping them close to military targets. In relation to the 2006 conflict, Israel's explanation was that Hezbollah placed missile launchers in civilian centers on purpose. NATO used a similar argument when it came to the 1999 war in Kosovo. Throughout the empirical chapters, each addressing a specific armed conflict, the author argued that such explanations only account for a small percentage of civilian casualties.

Cronin explains that, even though, in 1991, Iraq held 800 foreign nationals as human shields at various installations in Iraq and Kuwait, all of them were released prior to the beginning of the armed conflict. He asserts that there is no evidence that Iraq used civilians as human shields during the conflict. In Chapter 5, the author shows that Hezbollah did sometimes hide military equipment in civilian neighborhoods and that its militants often did not wear anything that would designate them as combatants. Yet, according to "Human Rights Watch", there was no evidence that this practice was recurrent or caused a significant portion of civilian casualties. The main threat to Israel was posed by Hezbollah's rocket launchers, and the Israeli attacks on these military assets caused few fatalities. Most of the civilian fatalities resulted from Israel's attacks against schools, shops, and other civilian institutions run by Hezbollah that Israel categorized as military assets. Overall, most of these targets in both cases were political and economic institutions, communication centers, and enterprises that had functioned for a long time before the 2006 conflict. The author points out that there is little evidence that authorities or armed groups in these two regions relocated military assets in urban areas. Instead, he argues that it was the Western forces that decided to include populated areas in the battlefield by defining such facilities as military targets. 
Why would the Western militaries do so? According to Cronin, the non-respect of the principle of civilian immunity is intrinsic to and stems from the prevailing Western war-fighting strategies.

The Western way of war. In Chapter 2, Cronin highlights five criteria that define the "classic" contemporary Western way of war: military engagement should be short, wars should be fought far away from home, cause only few casualties on the intervener's side, and preferably end in a decisive victory (instead of being settled through long and difficult negotiations). He then discusses the notions of risk transfer and effects-based strategies. $\mathrm{He}$ cites several defense analysts and senior U.S. military commanders who point at the extent to which the American people's support for war depends on the military casualties among the coalition troops. The fewer casualties for the U.S. soldiers, the stronger support for a war by the American people. The author argues that this is a factor that explains the U.S. actions in Iraq when the U.S. forces attacked Iraqi cities instead of targeting the Iraqi forces in Kuwait to expel them. Indeed, this strategy that unsurprisingly resulted in massive collateral damage was pursued to prevent a ground war with Iraqi forces in Kuwait and thus avoid casualties among coalition soldiers. Moreover, coalition aircraft were flying at very high altitudes making it difficult to verify the presence of noncombatants. The purpose was to avoid potential anti-aircraft attacks, even though such a threat was low. A similar strategy of avoiding ground war was pursued in Serbia, even though deploying ground forces would have resulted in more effective protection of the Kosovars (Kosovo Albanians). Cronin qualifies such strategies as risk transfer: the Western militaries transfer risks from their soldiers to local civilians.

Cronin adds that the Western way of war often relies on an effects-based approach, which he defines as "operations [that] employ military force for the purpose of undermining the political and economic foundations of the adversary's base of power, and define success by the degree to which they can destabilize the systems and 'centers of gravity' on which the enemy relies". ${ }^{1}$ To cut it short, it is a strategy aimed at destroying parts of the opponent's society. Such a strategy is the fruit of technological innovation in the military sphere, especially in air power. Attacks on the Iraqi cities, mentioned above, could be used as an illustration of the effects-based approach that increases the probability of capitulation of the attacked country, and thus a decisive victory, at the expense of civilians.

To summarize Cronin's book in one sentence: if the level of civilian casualties is so high, it is not because civilians are used as human shields by the adversaries, but mainly because of the Western way of war that involves risk transfer and effects-based strategies.

Inconclusive conclusion: would there really be fewer civilian casualties save the Western way of war? Cronin's conclusion is two-fold. His first conclusion is formulated from the moral and liberal standpoints: states that claim to adhere to the laws of war and the principle of civilian immunity should not do such things. His second conclusion is more down-to-earth: had the Western states not attacked civilian areas and objects, they would have still prevailed militarily, but without causing so many civilian deaths. Instead of discussing morality and the ethics of war, this review focuses on Cronin's second conclusion that is realist in nature and is based on a cost-benefit approach. When explaining the effects-based strategy in Chapters 2 and 7, Cronin argues that such strategy requires advanced military technology, especially air power. Developing, producing and deploying such military assets certainly cost no less, if not more, than sending military troops to fight battles on the ground. So if Cronin's second conclusion is correct, then why would the Western militaries and governments waste so much money and so many civilian lives if the same result could be achieved by using more limited resources? 
When major powers intervene, casualties do go up, but what matters is how long the conflict goes on. ${ }^{2}$ While fatality numbers increase in the short term, most of the conflicts discussed in this book lasted less than three months, and having a short armed conflict is one of the characteristics of the "Western way of war". It is perhaps bold to assume that a conflict without any intimidating effects-based strategy (and a much more protracted one) would necessarily result in fewer civilian fatalities and overall casualties.

Let's take Cronin's example of the U.S. air attacks on the Iraqi towns, with the U.S. aircraft flying at altitudes too high to identify non-combatants and to distinguish them from combatants. This war lasted for only forty-two days; while civilian casualties were high because of the full use of the risk transfer and effects-based strategies, the non-use of these two strategies would not have ensured any fewer civilian casualties. Indeed, a longer war could have caused larger collateral damage, due to accidents, weapons malfunction, spill-overs or target misidentification (the classical definition of collateral damage according to the U.S. Department of Defense). For ethics-centered liberals, this essentially boils down to the well-known philosophical "trolley problem": is it moral to voluntarily sacrifice one person to save two others? For utilitarian realists, the answer is clear: if we can have the same results in less time and at the cost of fewer deaths, this leaves no place for debates on morality.

Perhaps playing devil's advocate, one could suggest that Cronin's conclusion is not a very consistent one, as he assumes that states can get the same results by killing fewer civilians and using fewer resources, and does not give a reason why they do not do so.

A hesitant yet well-grounded attack at the notion of collateral damage. On the one hand, Cronin's book successfully challenges the deontological aspect of the notion of "collateral damage", even though the author often avoids calling things what they are. Collateral damage implies incidental civilian casualties resulting from a military action when causing harm to civilians is not the goal of such action. However, Cronin's explanation of the "Western way of war" suggests that civilians are often targeted on purpose.

On the other hand, qualifying such expected and pre-assumed collateral damage as one-sided violence would perhaps be too extreme. It does not seem to fit the "classic" definition of one-sided violence formulated by the Uppsala University Conflict Data Program (UCDP): in most cases, the Western states' end goal is to intimidate the adversary and win the war, and not just to kill civilians per se. ${ }^{3}$ Cronin is indeed sometimes hesitant in straightforwardly asserting that, in those case studies that he addresses in the book, the Western states attacked civilians on purpose. For instance, in Chapter 5 he argues that Israel's labeling of Hezbollah-run civilian institutions as "legitimate" military targets was based more on Israel's overall thorny relationship with Hezbollah than on the relevance of these civilian objects to the conflict. This wording makes it sound as if the destruction of these civilian objects has no relevance to the conflict, even though the whole point of the effects-based strategy is to erode elements of national/local power and society.

It is estimated that around half of all battle-related deaths worldwide are civilian (and this does not include victims of intentional, one-sided violence that specifically targets civilians and also mostly takes place in areas of armed conflicts). However, as Cronin shows throughout his book, civilians can also be used as a tool to win wars. He also shows how traditional military objectives of getting rid of the adversary's military assets and troops are now becoming outdated. Nowadays, parties in armed conflicts seek to erode not only what is valued by military forces, but also what is valued by the population. As destroying civilians and civilian (socio-economic, educational, information 
and other) objects increasingly becomes a tactic to win wars, it is only logical to suggest that it is civilians that should become the main object of security. Cronin's book effectively leads us to this conclusion, by drawing attention to civilians in war, civilian casualties, and human security.

Annie Avagyan, MGIMO-University*

\section{ENDNOTES}

${ }^{1}$ Cronin B. Collateral damage and Western war-fighting strategy // Cronin B. Bugsplat: the Politics of Collateral Damage in Western Armed Conflicts. - New York: Oxford University Press, 2018. P. 50.

2 Pettersson T., Öberg M. Organized violence, 1989-2019 // Journal of Peace Research. V. 57. № 4. 2020. P. 597-613.

3 UCDP Definitions. Uppsala Conflict Data Program (UCDP), Department of Peace and Conflict Research, Uppsala University. URL: https://www.pcr.uu.se/research/ucdp/definitions, accessed 26 October 2020.

\section{BIBLIOGRAPHY}

1. Cronin B. Bugsplat: the Politics of Collateral Damage in Western Armed Conflicts. - New York: Oxford University Press, 2018.

2. Pettersson T., Öberg M. Organized Violence, 1989-2019 // Journal of Peace Research. V. 57. № 4. 2020. P. 597-613. DOI: $10.1177 / 0022343320934986$.

3. UCDP Definitions. Uppsala Conflict Data Program (UCDP), Department of Peace and Conflict Research, Uppsala University. URL: https://www.pcr.uu.se/research/ucdp/definitions, accessed 26 October 2020.

\footnotetext{
* Annie Avagyan (Russia) is a student at the School of Government and International Affairs, MGIMOUniversity, Moscow.

Авагян Анни Рубеновна (Россия) - студентка Института международных отношений и управления МГИМО-Университета.
} 